Int. J. Plant Sci. 168(9):1255-1268. 2007.

(c) 2007 by The University of Chicago. All rights reserved.

1058-5893/2007/16809-0003\$15.00 DOI: $10.1086 / 521689$

\title{
POLLINATION ECOLOGY AND BREEDING SYSTEM OF XYLOPIA CHAMPIONII (ANNONACEAE): CURCULIONID BEETLE POLLINATION, PROMOTED BY FLORAL SCENTS AND ELEVATED FLORAL TEMPERATURES
}

\author{
R. M. C. S. Ratnayake, * I. A. U. N. Gunatilleke, † D. S. A. Wijesundara, $\neq$ and R. M. K. Saunders ${ }^{1, *}$ \\ *Division of Ecology and Biodiversity, School of Biological Sciences, University of Hong Kong, Pokfulam Road, \\ Hong Kong, China; †Department of Botany, University of Peradeniya, Peradeniya, \\ Sri Lanka; and ‡Royal Botanic Gardens, Peradeniya, Sri Lanka
}

\begin{abstract}
Data on the reproductive biology of the Annonaceae are rather fragmentary, particularly for paleotropical species. The pollination ecology and breeding system of the Sri Lankan endemic Xylopia championii (Annonaceae) are described in detail. The pollination ecology was investigated using a diverse range of approaches, including (1) observations of flower-level and population-level phenology, (2) assessments of floral visitors and effective pollinators, (3) monitoring of floral temperature in situ using a digital data logger, and (4) analysis of scent chemistry using solid-phase microextraction sampling and gas chromatography-mass spectrometry identification of volatiles. The breeding system was evaluated using pollen/ovule ratios and field-based controlledpollination experiments. Intrafloral dichogamy (protogyny) occurs over a $2-\mathrm{d}$ period, with a reproductively inactive phase between the pistillate and staminate phases, although there is no evidence of interfloral dichogamy. The inner petals close to form a pollination chamber during the reproductively active phases. The flowers are pollinated by a species of Endaeus weevil (Coleoptera: Curculionidae). Floral chamber temperatures are elevated to $8^{\circ} \mathrm{C}$ above ambient levels. The floral scent contains a combination of volatiles that have previously been observed in fruits and other flowers and that possibly mimic insect pheromones. Xylopia championii has an essentially xenogamous breeding system, promoted by protogyny. Although X. championii possesses numerous clear adaptations for cantharophily, there is no evidence for a species-specific interaction. The beetles are attracted to the flowers by strong scents; rewards offered to the beetles include heat energy and protection from predators. Low levels of fruit set in natural conditions suggest that pollinator availability may be a limiting factor.
\end{abstract}

Keywords: Annonaceae, breeding system, Coleoptera, Curculionidae, Endaeus, floral scent, floral temperature, pollination, Sri Lanka, Xylopia championii.

\section{Introduction}

Despite the accumulation of empirical data that suggests that the majority of angiosperm pollination systems are diversified and opportunistic (e.g., Waser et al. 1996), there is convincing evidence that the family Annonaceae possesses specialized pollination systems. Most Annonaceae species are beetle pollinated, with distinct small- and large-beetle pollination systems (e.g., Gottsberger 1999; Silberbauer-Gottsberger et al. 2003; Saunders, forthcoming), although a diverse array of other insect groups are reported to act as pollinators, including thrips (Bocageopsis, Duguetia, Oxandra, Popowia, and Xylopia: Gottsberger 1970; Webber and Gottsberger 1995; Küchmeister et al. 1998; Momose et al. 1998a, 1998b; Silberbauer-Gottsberger et al. 2003), flies (Asimina, Monodora, and Pseuduvaria: Gottsberger 1985; Norman et al. 1992; Su et al. 2005; Su and Saunders 2006), cockroaches (Uvaria: Nagamitsu and Inoue 1997), and bees (Sapranthus, Unonopsis, and Uvaria: Olesen 1992; Carvalho and Webber 2000; Silberbauer-Gottsberger et al. 2003). In general, how-

${ }^{1}$ Author for correspondence; e-mail saunders@hkucc.hku.hk. Manuscript received March 2007; revised manuscript received June 2007. ever, relatively few Annonaceae species are restricted to a single species of pollinator.

Available data on the pollination ecology and breeding systems of the Annonaceae are rather fragmentary, particularly for paleotropical species. Xylopia is one of the largest genera in the family, with up to 160 species (Keßler 1993), and is the only pantropical genus in the family. Published data are only available for seven species, namely Xylopia amazonica (Webber 2002; Silberbauer-Gottsberger et al. 2003), Xylopia aromatica (Gottsberger 1970; Jürgens et al. 2000; Silberbauer-Gottsberger et al. 2003), Xylopia benthamii (Jürgens et al. 2000; Webber 2002), Xylopia bocatorena (Kress and Beach 1994), Xylopia brasiliensis (Andrade et al. 1996), Xylopia crinita (Küchmeister et al. 1998), and Xylopia excellens (Küchmeister et al. 1998; Silberbauer-Gottsberger et al. 2003). All these species are pollinated by small beetles, with the exception of $X$. amazonica, which is pollinated by thrips, and X. aromatica, which is pollinated by a combination of thrips (ca. $80 \%$ of visits) and small beetles (ca. $20 \%$ ).

The reproductive biology of the Sri Lankan endemic $X y$ lopia championii is described here in detail. This is the first such study for a paleotropical species of Xylopia. The flowers are typical of other species in the genus, with a whorl of three small sepals and two whorls of fleshy, yellowish-cream 
petals (fig. 1A). During the reproductively active phases, the inner petals become compressed against each other, forming an enclosed pollination chamber over the reproductive organs (fig. 1A). The flowers are hermaphroditic, with numerous densely packed, spirally arranged stamens around an extended receptacle (fig. $1 B$ ). Each stamen has a tongue-shaped connective extension. A solitary carpel is located within a cavity formed by the extended receptacle so that the ovary is protected, and only the stigma is exposed above the top of the stamens.

The pollination ecology of $X$. championii is investigated in this article using a diverse range of approaches, including observations of flower-level and population-level phenology, floral temperature, scent chemistry, and assessments of floral visitors and effective pollinators. Corresponding data on the breeding system are also presented, using pollen/ovule ratios and field-based controlled-pollination experiments.

\section{Material and Methods}

\section{Study Site}

Field observations were conducted in the Sinharaja World Heritage Site in southwest Sri Lanka (fig. 2). Sinharaja Forest Reserve $\left(06^{\circ} 21^{\prime}-26^{\prime} \mathrm{N}, 80^{\circ} 21^{\prime}-34^{\prime} \mathrm{E}\right)$ is located in southern Ratnapura District and northern Galle District and hence lies within the lowland wet vegetation zone. Sinharaja covers 11,187 ha, of which 8860 ha is designated as part of the reserve and is therefore comparatively undisturbed (Gunatilleke and Gunatilleke 1981). The mean annual temperature recorded for the area is $25^{\circ}-27^{\circ} \mathrm{C}$, and the mean annual rainfall is 4000-6000 mm (Ashton et al. 1995); the rainfall is largely derived from the southwest monsoon during May to
July and the northeast monsoon during November to February. The vegetation is accordingly lowland and submontane tropical wet evergreen forest (Davis et al. 1995).

Fifty trees of Xylopia championii were permanently labeled with metal tags and used in all phenological and experimental studies. The tagged trees were $4-15 \mathrm{~m}(x=8.5 \mathrm{~m})$ in height and $27.5-84.5 \mathrm{~cm}(x=48.5 \mathrm{~cm})$ diameter at breast height $(\mathrm{dbh})$. The size of reproductively mature individuals necessitated the construction of wooden platforms, which inevitably limited the extent of observations of pollinator activities and the number of individuals used in the controlledpollination experiments. Voucher specimens (R. M. C. S. Ratnayake 03/03) have been deposited in HKU and PDA herbaria.

\section{Floral Morphology and Phenology}

Population-level phenological studies were conducted weekly over a 3-yr period (March 2002-March 2005) to determine the timing of the beginning and end of flowering, the peak flowering times, and whether anthesis is synchronized within and/or between individuals. Flower-level phenological changes were monitored by tagging 10 unopened flowers on five individuals of each species. Observations of floral morphology and sexual functioning were made daily before the onset of stigmatic receptivity and subsequently every hour. Changes in the following morphological characters were assessed: length and width of petals, relative position and shape of petals, color of petals and stamens, and wilting and abscission of floral organs.

The timing of the onset of stigmatic receptivity and its duration were also assessed. Receptivity was initially determined by immersing stigmas in $3 \%$ hydrogen peroxide $\left(\mathrm{H}_{2} \mathrm{O}_{2}\right)$ solution and checking for bubble formation (Dafni 1992); bubbles form as a result of the activity of peroxidase enzymes and are
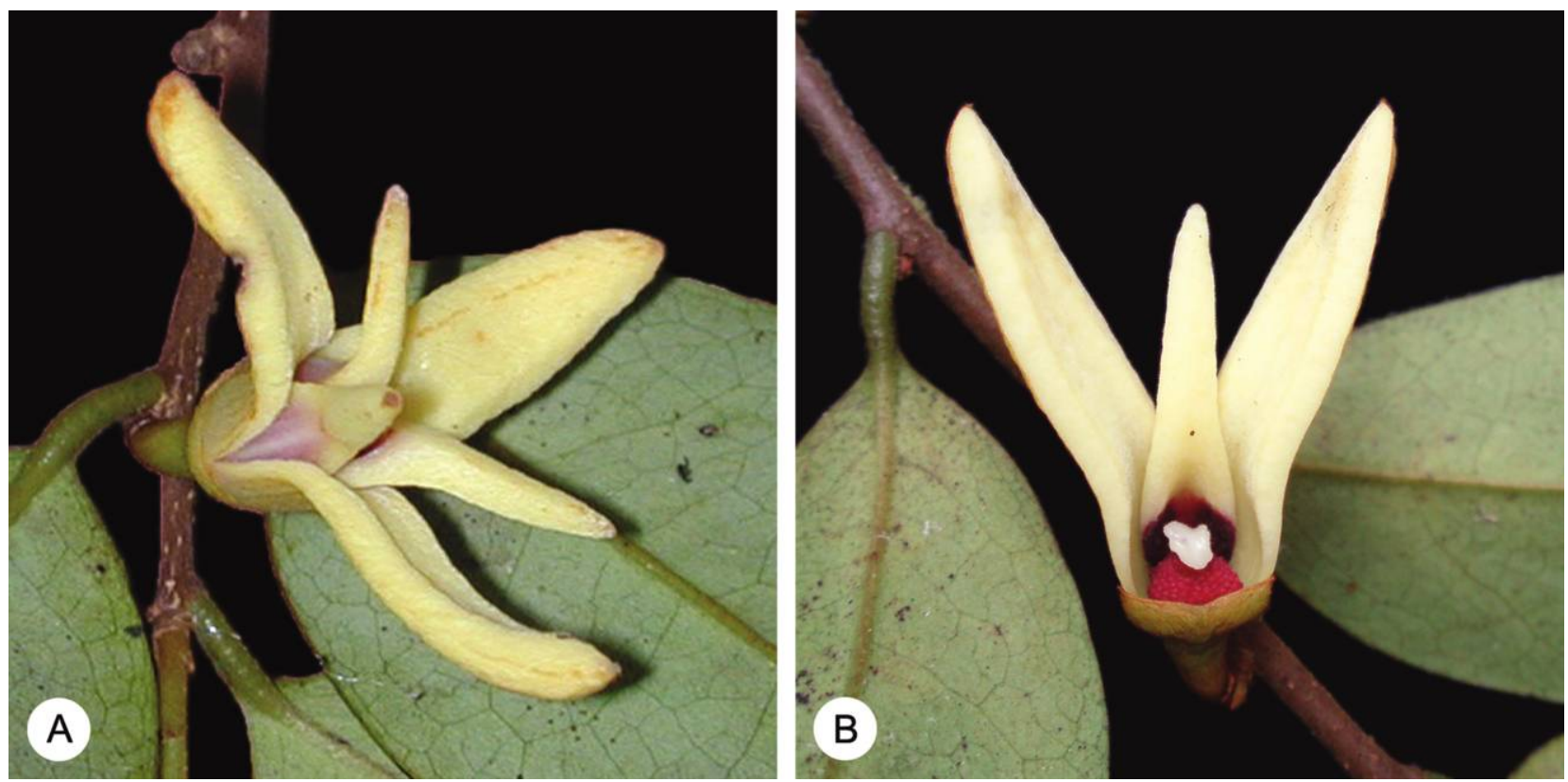

Fig. 1 Mature flowers of Xylopia championii. A, Entire flower, showing connivent inner petals. B, Dissected flower, with one outer petal and two inner petals removed to show numerous stamens (red) surrounding stigma (white); note also deep red pigmentation at base of inner petal. 


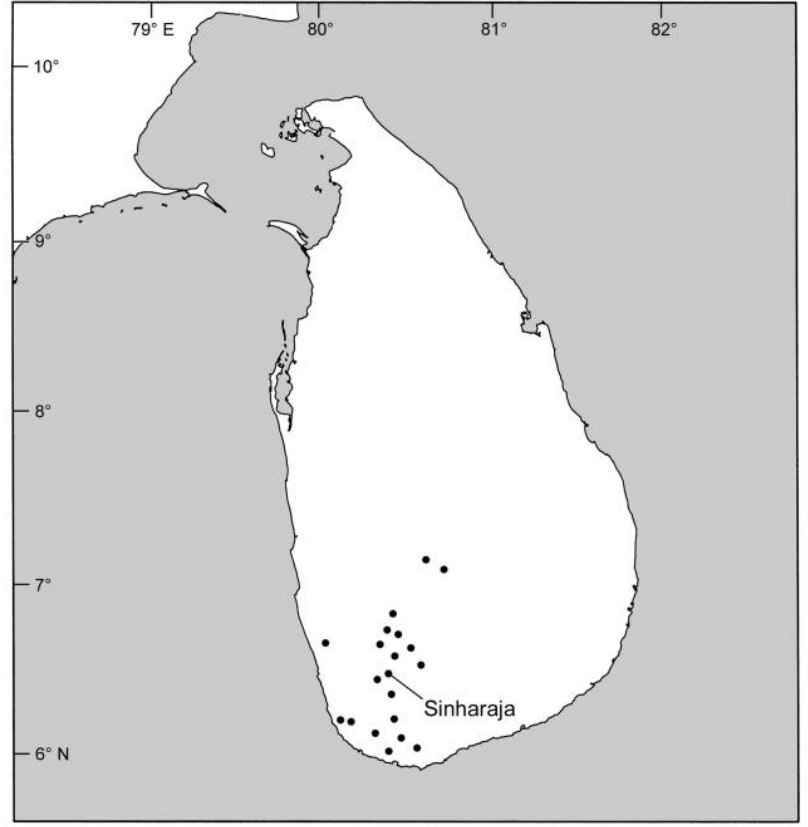

Fig. 2 Location of Sinharaja Forest and distribution of Xylopia championii in Sri Lanka (data abstracted from Huber 1985).

indicative of receptivity (Galen and Plowright 1987). Stigmatic receptivity was found to coincide with the appearance of a glistening stigmatic exudate, enabling a simple visual determination of receptivity. The onset of the staminate phase was readily apparent due to the mass release of pollen and color changes of the staminal connectives.

\section{Floral Visitors and Pollinators}

Extensive observations of the activities of floral visitors were undertaken during daylight hours (0600-1800 hours), supplemented with periodic nighttime observations to ensure that cumulative observations covered the entire anthesis period, from the onset of stigmatic receptivity to the end of the staminate phase. Hourly observations were based on a total of 15 flowers from five individuals; this data set was supplemented by numerous additional observations, recorded while monitoring flower-level phenology and floral temperature, and during the controlled-pollination experiments. The number and types of floral visitors were recorded by careful observation of the floral chamber without disturbance of visitors, with samples collected for subsequent identification. The arrival times and activities of the floral visitors were observed whenever possible.

\section{Floral Temperature}

Temperatures within the floral chambers (Seymour et al. 2003) were recorded using a digital data logger (DataTaker DT 800, DataTaker, Rowville, Australia), with type K thermocouples (welded tip, glass fiber insulated, $0.6 \mathrm{~mm}$ diameter, temperature resolution $\pm 0.0075^{\circ} \mathrm{C}$ ). Using 15 flowers, measurements were made at 10 -min intervals from immediately before the onset of the pistillate phase until petal abscission. Ambient air temperature data were collected simultaneously at 10 -min intervals, using a Vaisala 50Y temperature sensor (Vaisala Oyj, Helsinki, Finland) attached to the same data logger. The temperature probes were fully cross-calibrated to ensure data consistency.

\section{Floral Scent}

Scent-producing flowers (pistillate and staminate phases) were collected with previously unused polypropylene bags (Azuma et al. 2001), which were immediately sealed to limit air movement. Solid-phase microextraction (SPME) samples were taken using fibers with a $65-\mu \mathrm{m}$ divinylbenzene/polydimethylsiloxane coating; these have recently been shown to be preferable to those with a $100-\mu \mathrm{m}$ coating (Goodrich et al. 2006). The fibers were held in a syringelike manual-sampling device (Supelco, Bellefonte, PA) and inserted into the bag for $2 \mathrm{~h}$ to enable adsorption of volatile compounds. The fibers were then transported to the laboratory for gas chromatographymass spectrometry (GC-MS) analysis. Three replicate samples from different trees were analyzed. In order to detect volatiles that are merely experimental artifacts, controls were run using SPME fibers in empty polypropylene bags.

The GC-MS analysis was performed with an Agilent 5973 mass selective detector connected to an Agilent $6890 \mathrm{~N}$ GC (Agilent Technologies, Palo Alto, CA) with a $30 \mathrm{~m} \times 0.25 \mathrm{~mm}$ i.d. DB-WAX capillary column with a $0.25 \mu \mathrm{m}$ film (J and W Scientific, Folsom, CA). Samples were injected into the gas chromatograph using helium as the carrier gas, and the following temperature combinations were applied: the oven was initially maintained at $50^{\circ} \mathrm{C}$ for the first $5 \mathrm{~min}$ and then increased at a rate of $5^{\circ} \mathrm{C} / \mathrm{min}$ to a maximum of $230^{\circ} \mathrm{C}$ for 20 min. Electrical ionization mass spectrometry was used, with an acquisition range of $30-650 \mathrm{~m} / \mathrm{z}$. The NIST $02 \mathrm{MS}$ library bundle (National Institute of Standards and Technology, Gaithersburg, MD) was screened for compounds with comparable mass spectra in order to identify volatile compounds, although the identities are necessarily rather equivocal in the absence of comparisons against authentic standards. Compounds with identity likelihood estimated at less than $80 \%$ in both pistillate- and staminate-phase flowers were treated as unknown compounds. Kovats indices (Kovats 1965) were calculated post hoc against n-alkane standards to provide confirmation of compound identity. The GC-MS analyses were not run under isothermal conditions, and therefore smaller alkanes separated during the first 5 min were not comparable to those separated subsequently; Kovats indices consequently could not be calculated for floral scent compounds with short retention times.

\section{Plant Breeding System}

The breeding system was assessed using two approaches: calculating the pollen/ovule $(\mathrm{P} / \mathrm{O})$ ratio and conducting a series of field-based controlled-pollination experiments. The ratio of the number of pollen grains and ovules produced by a flower can be used as an approximate indicator of breeding system, as follows (Cruden 1977): 2.7-5.4 suggests cleistogamy; 18.1-39.0 suggests obligate autogamy; 39.1-396.0 suggests facultative autogamy; 244.7-2588 suggests facultative xenogamy; and 2108-195,525 suggests obligate xenogamy. The numbers of pollen grains and ovules were counted using 
standard techniques (Dafni 1992), based on 10 flowers from five individuals.

In order to determine whether viable pollen was available for controlled-pollination experiments, pollen germination rates were assessed in vitro using artificial sucrose solutions at ambient temperatures. Sucrose solutions of various concentrations $(0 \%, 5 \%, 10 \%, 20 \%$, and $25 \%)$ were prepared and mixed with $50 \%(\mathrm{w} / \mathrm{v}) \mathrm{H}_{3} \mathrm{PO}_{3}$ and $50 \% \mathrm{Ca}(\mathrm{NO})_{3}(\mathrm{w} / \mathrm{v})$ (Dafni 1992). Mature pollen was collected from 10 flowers from each of five individuals immediately after anther dehiscence and mixed with $10 \mu \mathrm{L}$ of each sucrose solution on glass cavity slides. The slides were maintained in closed petri dishes with damp filter paper at ambient temperatures for $24 \mathrm{~h}$. One hundred pollen grains were visually assessed to determine the proportion of pollen grains germinating, using six replicates of each treatment.

Controlled-pollination experiments were conducted at the beginning of the peak flowering season. The flowers were covered with chiffon cloth bags to exclude pollinators (Dafni 1992) before the onset of stigmatic receptivity. Pale green cloth was used as camouflage to protect the bagged flowers from attack by animals, monkeys in particular. The field experiments involved 132-260 flowers (varying between treatments) from eight individuals.

A total of four different controlled-pollination treatments were conducted (adapted from Dafni 1992) to determine breeding system: (1) control-flowers not bagged and left to freely pollinate; (2) test for geitonogamy-flowers bagged and artificially pollinated with pollen from another flower of the same individual that had previously been bagged; (3) test for xenogamy-flowers bagged and artificially pollinated with pollen from flowers of a different individual (10-100 m from recipient); (4) test for autogamy-flowers bagged but not artificially pollinated. Standard pollination treatments requiring emasculation of the flowers were not possible, since the flowers inevitably withered and abscised before the onset of stigmatic receptivity. The strong protogyny shown by flowers of both species (data presented in this article) precludes intraflower self-pollination (autogamy), and consequently pollination treatment 4 can also be regarded as a test for agamospermy. Since autogamous self-pollination is not possible, all references to "self-pollination" in this research refer to geitonogamous pollination (between different flowers of the same individual).

In the absence of clearly discernible external morphological changes associated with postpollination events, it was not possible to record with certainty the extent of pollination success until 2 wk after petal abscission. The number of fruits that developed after each treatment were assessed at 2 -wk intervals until fruit maturity (after ca. $20 \mathrm{wk}$ ). The overall time between pollination and fruit maturity was recorded for each species. The percentage fruit set in relation to the number of the flowers pollinated in each treatment was also calculated. Some treated flowers were unavoidably destroyed by monkeys and were consequently excluded from the analyses. The statistical significance of comparisons between different pollination treatments and between different individuals were assessed by ANOVA on rank after testing for equal variance and discriminated using the Tukey test for unequal $n$ (Spjotvoll/Stoline test). Comparison of the number of developing monocarps be- tween different treatments required log transformation to satisfy statistical assumptions of normality. All statistical analyses were undertaken using Minitab software (Minitab 2001).

A quantitative evaluation of possible self-incompatibility was achieved using the index of self-incompatibility (ISI) developed by Zapata and Arroyo (1978). The ISI was calculated by dividing the percentage of fruits resulting from self-pollination by the percentage of fruits derived by cross-pollination. Resultant ISI values reflect the following possibilities: $0=$ completely self-incompatible; $0-0.2=$ mostly self-incompatible; $0.2-1=$ partially self-incompatible; and $>1=$ self-compatible (Zapata and Arroyo 1978).

\section{Results}

\section{Floral Morphology and Phenology}

Although Xylopia championii flowers are typically hermaphroditic, a small proportion of the flowers examined in the field (ca. $5 \%$ ) were found to be functionally staminate. These staminate flowers did not appear to be restricted to specific individuals. The receptacle was deeply concave, as in hermaphroditic flowers, although the central cavity contained an aborted, nonfunctional carpel (fig. 3). There was no apparent difference in the number of stamens in these flowers, and the pollen was viable.

At the population level, flowering was continuous in $X$. championii, although with a major flowering peak from December until April. Flowering of most of the individual trees was synchronized within the population during the peak flowering period, although there were some early- or late-flowering individuals. The flowering intensity of the trees was consistently low, with a maximum of only five reproductively active flowers borne concurrently on an individual tree, and there were days within the flowering period when a reproductively active tree did not bear any functional flowers. Casual observations suggest that there is no interfloral dichogamy: pistillatephase flowers often occur alongside staminate-phase flowers within the same tree.

Xylopia championii flowers undergo several distinct developmental changes before, during, and after periods of sexual receptivity. For ease of discussion, we have categorized these changes into six different phases (referred to as stages I-VI: table 1; fig. 4). The flower buds and mature flowers were invariably pendent, with relatively little change of petal color throughout the six stages observed except for the intensification

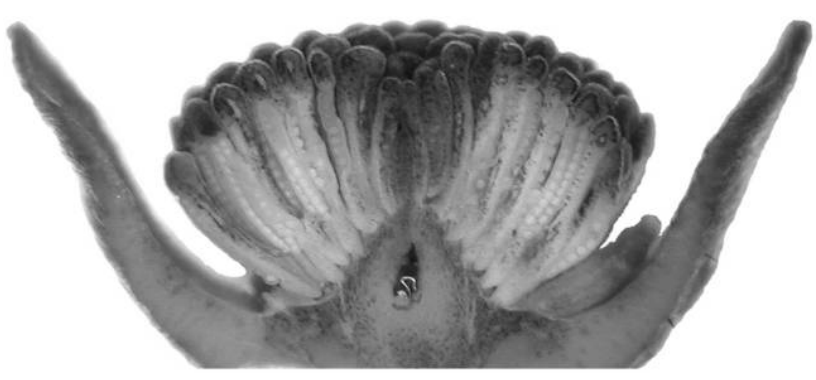

Fig. 3 Staminate flower of Xylopia championii (longitudinal section, after removal of corolla). 
Table 1

Flower-Level Phenological Stages in Xylopia championii

\begin{tabular}{|c|c|c|c|c|c|c|}
\hline $\begin{array}{l}\text { Floral } \\
\text { stage }\end{array}$ & Duration & Petal position & $\begin{array}{c}\text { Inner and outer } \\
\text { petal color (general) }\end{array}$ & $\begin{array}{c}\text { Inner petal color } \\
\text { (basal adaxial region) }\end{array}$ & Stamen color & $\begin{array}{l}\text { Reproductive } \\
\text { activity }\end{array}$ \\
\hline I & $25-30 \mathrm{~d}$ & Closed & Greenish yellow & Pale pink & Not visible & None \\
\hline II & $1-2 \mathrm{~d}$ & Gradually separate & Pale yellow & Pink & Not visible & None \\
\hline III & $6-8 \mathrm{~h}$ & Fully separated & Light yellow & Pink-purple & Pink & None \\
\hline IV & $15-17 \mathrm{~h}$ & $\begin{array}{l}\text { Outer petals partially closed; } \\
\text { inner petals form a tightly } \\
\text { closed chamber }\end{array}$ & No change & Pink-purple & No change & Stigmas receptive \\
\hline $\mathrm{V}$ & Ca. $6 \mathrm{~h}$ & Fully separated & No change & Red-purple & No change & None \\
\hline VI & Ca. $17 \mathrm{~h}$ & Same as stage IV & No change & Dark red-purple & Dark maroon & Anther dehiscence \\
\hline
\end{tabular}

of the red pigmentation at the base of the petals adaxially (fig. 1B).

The unopen flower buds of $X$. championii were observed to develop over a prolonged period of 25-30 d (stage Ia-Ic; fig. $4)$, during which period the petals gradually turned yellow. The petals subsequently separated over 1-2 d (stage II): although the outer petals separated fully, the base of the inner petals initially remained in contact with each other immediately above the reproductive organs, forming an enclosed pollination chamber (stage IIa, IIb; fig. 4), only separating fully toward the end of stage II (stage IIc, IId; fig. 4). The petals subsequently reflexed outward over a period of $6-8 \mathrm{~h}$ (stage III; fig. 4) immediately before the flowers became sexually receptive.

The flowers were markedly protogynous, with the entire extent of reproductive activity restricted to a $2-\mathrm{d}$ period. The pistillate phase (stage IV) lasted for ca. $15-17 \mathrm{~h}$ (fig. 5), from ca. 1500 hours on day 1 to 0600-0800 hours on day 2. During this phase, the petals closed so that the inner petals formed a pollination chamber over the reproductive organs (fig. 4), and the stigma was noticeably wet due to the secretion of a sticky exudate. This phase was clearly correlated with the emission of a strong fruity odor.

The pistillate phase was succeeded by an interim period (stage V; fig. 4) of 6-8 h (fig. 5), during which the flowers were not sexually functional and floral scent dissipated. The petals again separated during this phase, and the flowers superficially resembled those of stage III.
The interim period was followed by a staminate phase (stage VI), during which the petals closed once again to form a pollination chamber (fig. 4), the anthers dehisced, and there was an obvious increase in floral scent. This stage continued for ca. $17 \mathrm{~h}$, from 1400 hours on day 2 to $0600-0800$ hours the following morning (fig. 5). The freshly dehisced pollen tetrads were loosely connected to each other, presumably due to the presence of a sticky pollenkitt. At the end of stage VI, the petals and stamens abscised, irrespective of whether the ovules had been fertilized or not.

\section{Floral Visitors and Pollinators}

A small unidentified weevil species belonging to the genus Endaeus (Coleoptera: Curculionidae) (fig. 6) was the most common visitor to $X$. championii flowers, with each floral chamber containing up to two or three individuals concurrently. The weevils landed on the calyx tube or outer petals before entering the floral chamber. If the floral chamber was fully closed, they entered by crawling between the inner petals. The weevils were crepuscular and nocturnal, with their arrival at the flowers occurring around 1800 hours on day 1 (3 in fig. 5). They remained overnight inside the floral chamber, before departing at around 0500-0800 hours the following morning ( 5 in fig. 5). Similar arrival and departure times were recorded for the beetles during the staminate phase the following night ( 8 and 9 in fig. 5). A correlation exists between the number of individuals per floral chamber and the
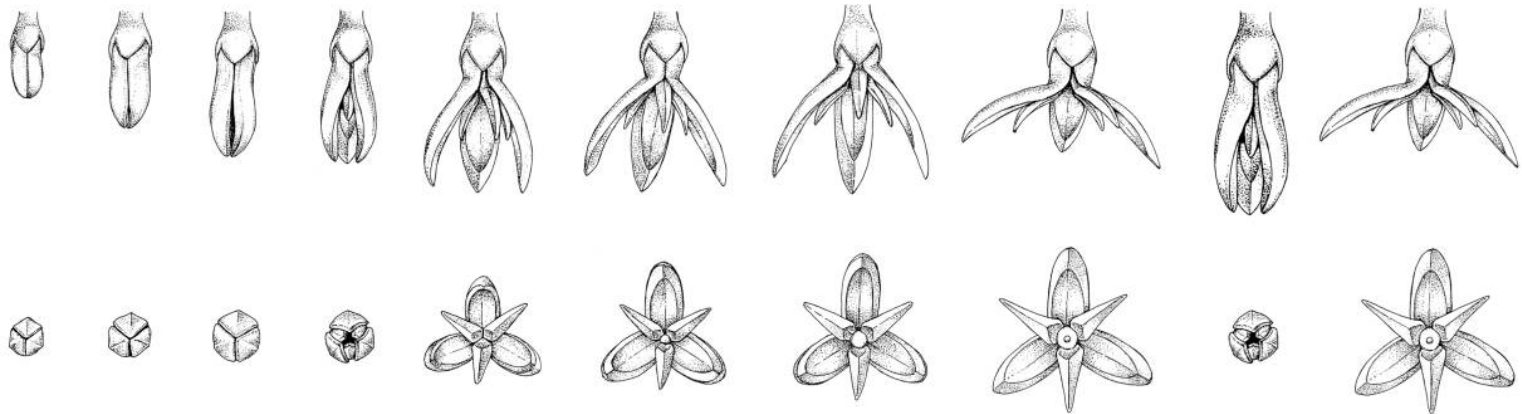

IId

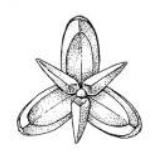

IIc

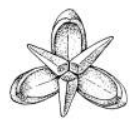

IIb
lla

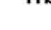

Fig. 4 Flower-level phenological changes in Xylopia championii, showing changes in size and position of petals. Upper row, lateral view; lower row, apical view. Roman numerals represent the six different phenological stages described in table 1 . Drawings by Ngai Yuen Yi. 


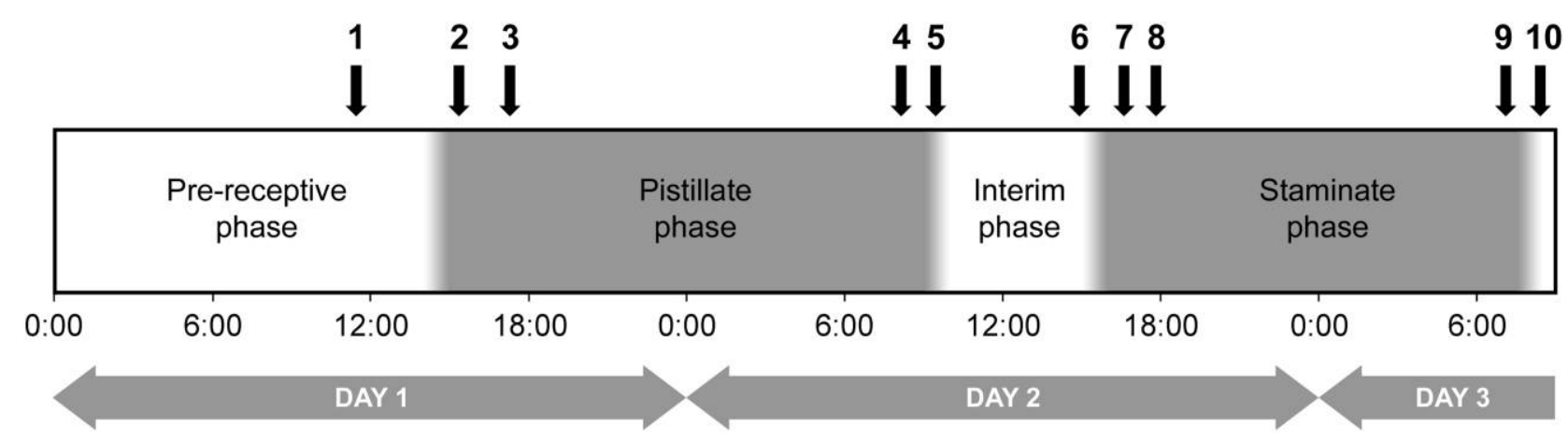

Fig. 5 Timing of phenological events during sexually functional phases of Xylopia championii flowers. Numerical codes: $1=$ inner petals form pollination chamber over reproductive organs; 2 =initiation of stigmatic receptivity, elevated floral temperature, and scent production; $3=$ arrival of pollinators; $4=$ departure of pollinators; $5=$ cessation of stigmatic receptivity and scent production and separation of petals; $6=$ inner petals form pollination chamber over reproductive organs; $7=$ initiation of anther dehiscence and scent production; $8=$ arrival of pollinators; $9=$ departure of pollinators; $10=$ abscission of stamens and petals and cessation of scent production.

occurrence of the pistillate and staminate phases of the flower (fig. 7), with a notable absence of weevils during the interim phase and before stigmatic receptivity. The weevils were generally present in pairs and were often observed copulating, although neither eggs nor larvae were ever observed in older flowers. Brown spots on the petals of flowers that had been visited by weevil suggests that the weevils may feed on petals. Pollen grains of $X$. championii were observed on the dorsal surfaces and mouth parts of the weevils. It can be conjectured that hairs on the bodies of the beetles assist with pollen attachment.

The only other floral visitor commonly observed was an unidentified species of ant (Formicidae). In general, only one or two individual ants were ever observed directly associated with the flowers.

\section{Floral Temperature}

There was clear evidence of elevated floral temperatures in $X$. championii (fig. 8), beginning immediately before the onset of stigmatic receptivity. The temperature within the floral chamber reached $30.3^{\circ} \mathrm{C}$ (ca. $8^{\circ} \mathrm{C}$ above ambient levels) during the pistillate phase (peaking around 1800-2000 hours), but fell to only ca. $1.3^{\circ} \mathrm{C}$ above ambient levels during the interim phase. During the staminate phase the following day, temperatures rose to $30.9^{\circ} \mathrm{C}$ (ca. $8^{\circ} \mathrm{C}$ above ambient levels) by ca. 1900 hours, and then gradually declined.

\section{Floral Scent}

Floral scent production was coincident with floral heat, with a gradual intensification of the scent associated with increasing floral temperatures. The fruity scent persisted throughout the pistillate phase, diminished during the interim phase, and then intensified again during the staminate phase.

The GC-MS analysis of floral volatiles revealed the presence of 43 volatile compounds, of which 19 were common to both pistillate- and staminate-phase scent (table 2). Three compounds (1,4-dichlorobenzene, butyrolactone, and naphthalene) were found to be present in the blank controls and were accordingly ignored since they are likely to be of anthropogenic origin or experimental artifacts. The chemical identifications presented are tentative, given the absence of comparative studies against authentic standards.

\section{Plant Breeding System}

The pollen grains are released as loose tetrads when the anthers dehisce. The mean numbers of pollen grains and ovules per flower were $12,969 \pm 952$ and $5 \pm 0.3( \pm \mathrm{SD})$, respectively, and the resulting $\mathrm{P} / \mathrm{O}$ ratio was accordingly $2625 \pm 219$.

The optimal sucrose concentration for pollen germination was $20 \%$; under these conditions, X. championii showed $30 \%( \pm 4.2 \mathrm{SD})$ pollen viability. These results therefore confirmed the feasibility of undertaking controlled-pollination experiments.

The overall time between pollination and fruit maturity was $115-130 \mathrm{~d}$ (mean $=122 \mathrm{~d}$ ). The 20 -wk monitoring of postpollination events therefore covered the entire developmental range up to the splitting of ripe fruits. Abscission of

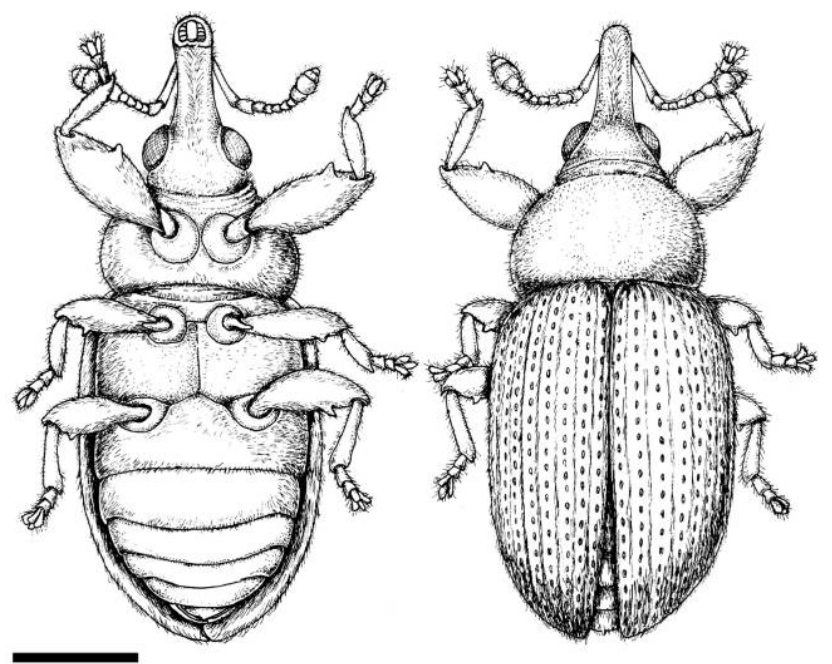

Fig. 6 Unidentified Endaeus species (Curculionidae), pollinator of Xylopia championii. Scale bar $=1 \mathrm{~mm}$. Drawings by Ngai Yuen Yi. 


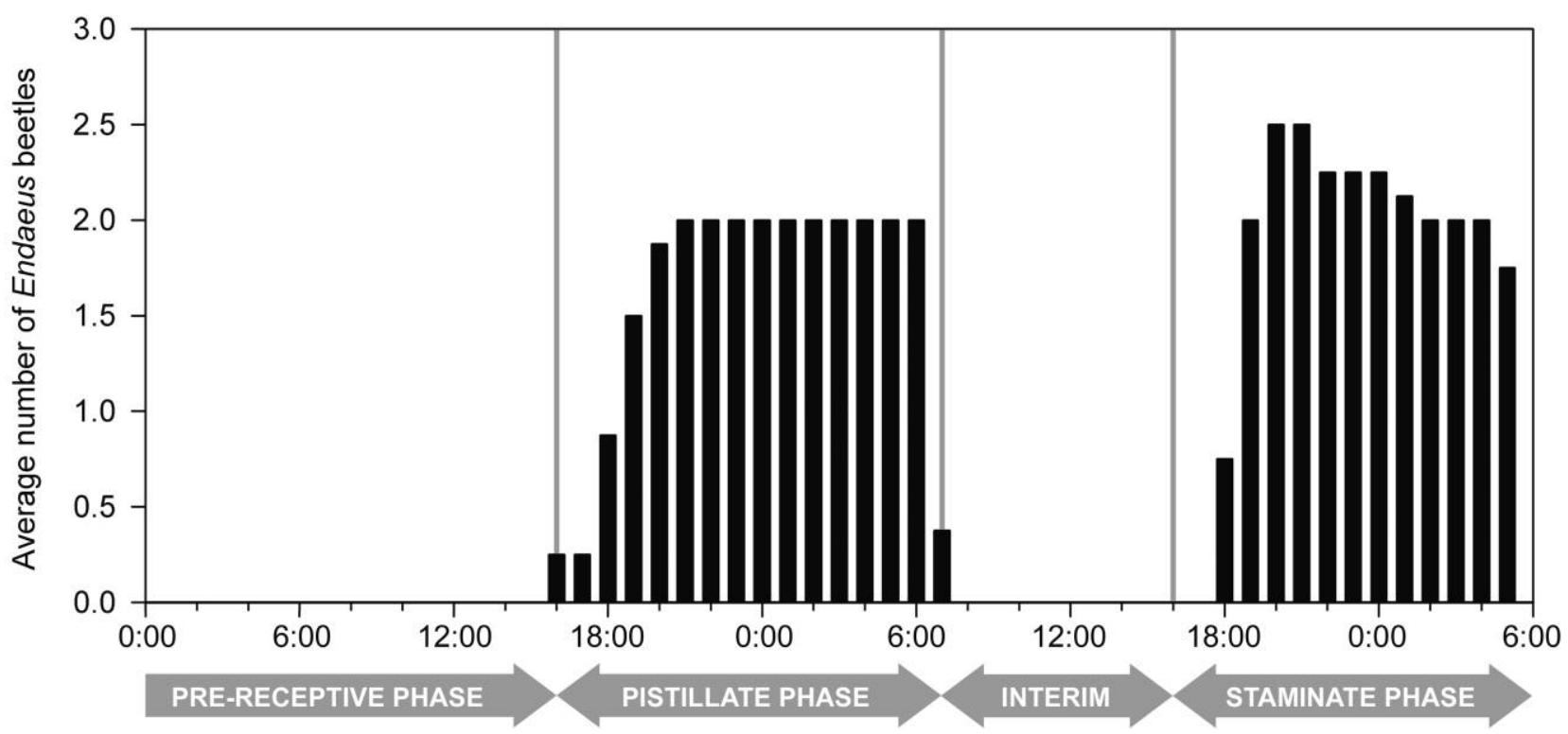

Fig. 7 Average number of Endaeus beetles per floral chamber in Xylopia championii.

entire flowers after 10-14 d was used as an indication of the failure of fertilization.

Flowers used as controls in the pollination experiments showed rapid abscission over the first few weeks, with $65 \%$, $82 \%$, and $88 \%$ of flowers dropping after 2,4 , and $6 \mathrm{wk}$, respectively (fig. 9). The remaining postfertilization flowers generally continued development, with relatively little subsequent abscission: after $20 \mathrm{wk}, 5.0 \%( \pm 3.4 \% \mathrm{SD})$ of flowers had resulted in fruit set (table 3 ). Flowers that had been bagged to exclude pollinators (without artificial pollination) showed a greater level of flower abscission, with $95 \%, 98 \%$, and $100 \%$ of flowers abscising after 2, 4, and $6 \mathrm{wk}$, respectively (fig. 9), with none resulting in mature fruits (table 3). Flowers that had either been artificially self-pollinated or artificially cross-pollinated showed a gradual rate of abscission over the 20-wk monitoring period (fig. 9), although with significantly different final rates of fruit set: $3.1 \%( \pm 1.7 \%)$ for those that had been self-pollinated and $29.4 \%( \pm 12.3 \%)$ for those that had been cross-pollinated (table 3 ).

Pollination success in the eight individuals studied was not significantly different (assessed using one-way ANOVA), indicating that there was no individual plant effect on pollination treatments. The differences among treatments were significant, however (table 3 ): the selfing rate of $X$. championii was significantly lower than that resulting from cross-pollination, although there was no significant difference between the selfpollination treatment and the control. The ISI was calculated as 0.10 .

\section{Discussion}

\section{Floral Morphology and Phenology}

Xylopia species (including Xylopia championii: Huber $1985)$ are invariably described as possessing hermaphroditic flowers. Our observation of staminate flowers in X. championii (fig. 3) appears to be unique in the genus, although the relatively small proportion of staminate flowers within populations (estimated at only 5\%) suggests that it would have negligible effect on breeding system.

Several of the structural features of the flowers of $X$. championii are likely to be adaptations for beetle pollination. Most significantly, the ovary is protected within a strongly concave receptacle; similar conditions are observed in Calycanthus and Eupomatia (Gottsberger 1974). As with most Annonaceae species, the stamens possess protective staminal connectives and are tightly packed around the receptacle to prevent access by beetles, only separating during anther dehiscence.

Although the petals of $X$. championii separate early in floral development, subsequent changes in the position of the inner petals result in the formation of a floral pollination chamber during the sexually receptive phases (fig. 4). Pollination chambers are widespread in the Annonaceae, although there is a striking diversity in structure: the chamber can be derived from the union of the convex adaxial surfaces of the inner petals (e.g., Polyalthia), imbricate inner petals (e.g., some Annona species), apically connivent inner petals (e.g., Goniothalamus and Orophea), or apically connivent outer petals (e.g., Dasymaschalon). The diverse structural basis of these chambers is presumably a reflection of their independent evolutionary origin within the family. The pollination chamber has several possible functions, including protection of pollinators from predators, providing brood sites for pollinators, and the maintenance of optimal temperature and humidity levels.

Xylopia championii is markedly protogynous, with a $6-8-\mathrm{h}$ interim period between the cessation of stigmatic receptivity and the onset of anther dehiscence (fig. 5). Protogyny has not only been widely reported in other Xylopia species (Andrade et al. 1996; Küchmeister et al. 1998; Webber 2002; Silberbauer-Gottsberger et al. 2003) but appears to be ubiquitous 


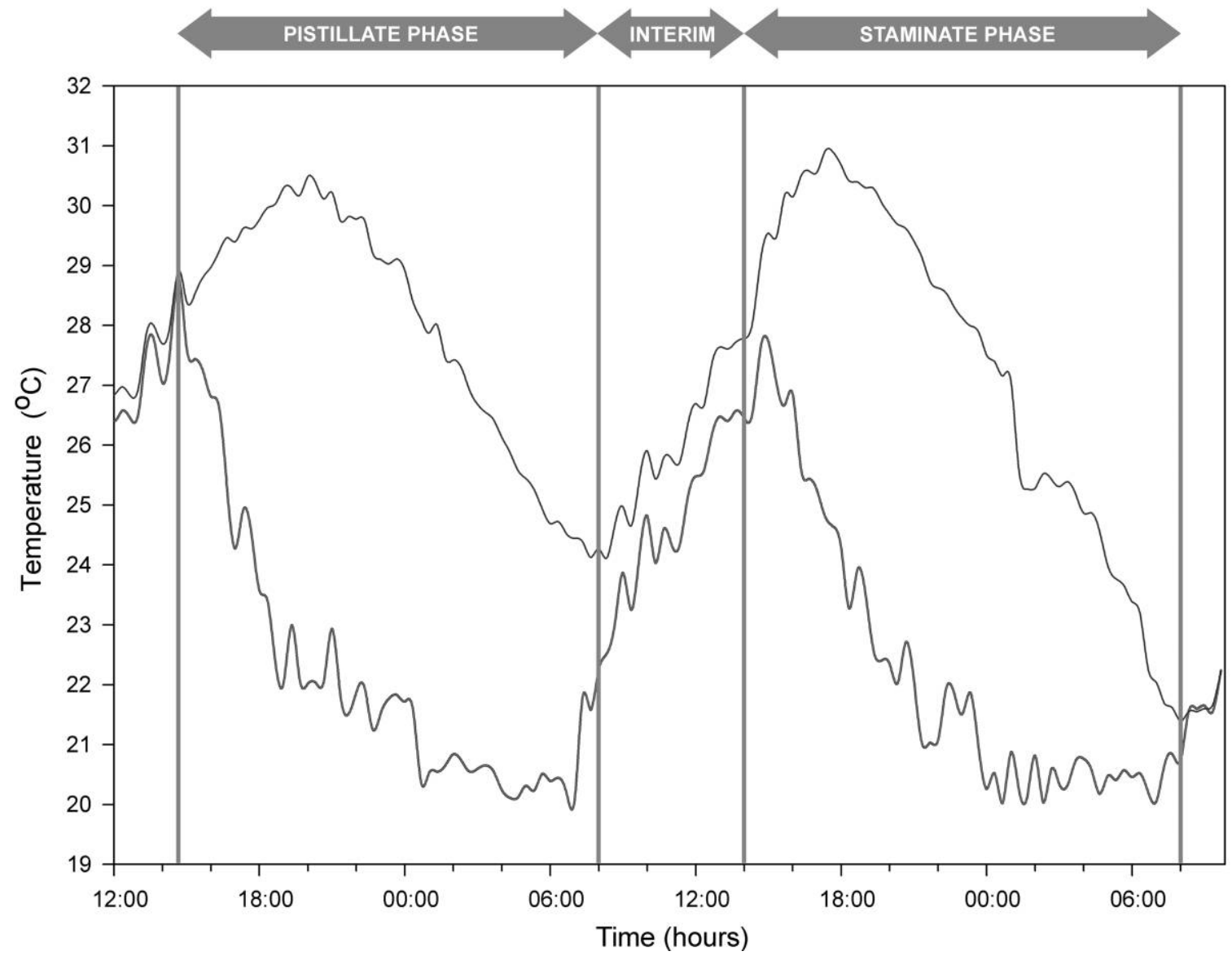

Fig. 8 Floral temperatures in Xylopia championii during pistillate, interim, and staminate phases. Upper line =internal flower temperature; lower line $=$ ambient temperature.

among species with bisexual flowers in the family as an adaptation to minimize the chances of within-flower pollination. The concurrent presence of pistillate- and staminate-phase flowers on the same individual of $X$. championii, however, allows possible geitonogamous pollination.

The reproductive cycle of individual flowers of Xylopia championii extends over $2 \mathrm{~d}$ (fig. 5). This is again common throughout the family (and has also been observed in Xylopia benthamii: Webber 2002), although species with unisexual flowers (e.g., Pseuduvaria; Silberbauer-Gottsberger et al. 2003) inevitably show a 1 -d cycle. Longer reproductive rhythms occasionally occur, as in Asimina (Willson and Schemske 1980; Norman and Clayton 1986; Norman et al. 1992; Rogstad 1993), Deeringothamnus (Norman 2003), and Monodora (Lamoureux 1975).

The timing of floral receptivity in X. championii is essentially crepuscular and nocturnal and inevitably coincides with periods of activity of the Endaeus floral visitors. This is typical of other beetle-pollinated Xylopia species (Andrade et al. 1996; Küchmeister et al. 1998; Jürgens et al. 2000; Webber 2002; Silberbauer-Gottsberger et al. 2003), whereas thrips-pollinated Xylopia species appear to be diurnal (Xylopia brasiliensis: Andrade et al. 1996; Xylopia aromatica: Jürgens et al. 2000).

\section{Floral Visitors and Pollinators}

The Endaeus weevil (Curculionidae) can be determined as an effective pollinator of $X$. championii on the basis of the following attributes: (1) their arrival time coincides with the onset of the functionally active phases of the flowers, with an increase in frequency during the pistillate and staminate phases and absence during the interim phase; (2) the body size (ca. $4 \mathrm{~mm}$ long, ca. $2 \mathrm{~mm}$ wide) is sufficiently small to enable them to be accommodated in the floral chamber; and (3) pollen grains of $X$. championii were observed attached to their bodies.

Although this is the first report of curculionid beetles as pollinators of Xylopia, other families of small beetles (Chrysomelidae, Nitidulidae, and Staphylinidae) have been reported previously for the genus (Andrade et al. 1996; Küchmeister et al. 1998; Jürgens et al. 2000; Webber 2002; Silberbauer-Gottsberger et al. 2003). Thrips (Thysanoptera) have also been shown to pollinate some species of Xylopia (Gottsberger 1970; Jürgens et al. 2000; Webber 2002; Silberbauer-Gottsberger et al. 2003). Pollination by small beetles (particularly Chrysomelidae, Curculionidae, Nitidulidae, and Staphylinidae) is extremely common in the Annonaceae (Gottsberger 1999; Silberbauer-Gottsberger et al. 2003) and is likely to represent the ancestral pollination system in the family. 
Table 2

Putative Chemical Composition of Floral Volatiles Emitted by Pistillate- and Staminate-Phase Flowers of Xylopia championii

\begin{tabular}{|c|c|c|c|c|c|c|c|}
\hline \multirow[b]{2}{*}{ No. } & \multirow[b]{2}{*}{ IUPAC compound name ${ }^{a}$} & \multirow[b]{2}{*}{$\begin{array}{l}\text { Mean RT } \\
(\min )\end{array}$} & \multicolumn{2}{|c|}{ Identity likelihood } & \multirow[b]{2}{*}{$\begin{array}{l}\text { Kovats } \\
\text { index }\end{array}$} & \multicolumn{2}{|c|}{ Percentage peak area } \\
\hline & & & $\begin{array}{l}\text { Pistillate } \\
\text { phase }(\%)\end{array}$ & $\begin{array}{l}\text { Staminate } \\
\text { phase }(\%)\end{array}$ & & $\begin{array}{l}\text { Pistillate } \\
\text { phase }\end{array}$ & $\begin{array}{l}\text { Staminate } \\
\text { phase }\end{array}$ \\
\hline 1 & 3,7,7-trimethylbicyclo[4.1.0]hept-3-ene [= 3-carene] & 7.10 & 74 & 87 & ... & 6.98 & 3.30 \\
\hline 2 & 1-methyl-4-(1-methylethyl)-1,4-cyclohexadiene & 8.46 & $\ldots$ & 87 & $\ldots$ & $\ldots$ & 1.25 \\
\hline 3 & Unknown & 9.48 & na & na & $\ldots$ & 2.63 & $\ldots$ \\
\hline 4 & Hexanoic acid, ethyl ester & 9.50 & 95 & 95 & $\ldots$ & 2.75 & 21.17 \\
\hline \multirow[t]{2}{*}{5} & 1-methyl-2-(1-methylethyl)-benzene & 10.45 & 95 & 95 & $\ldots$ & 3.03 & 1.76 \\
\hline & 1-methyl-4-(1-methylethyl)-benzene [= $p$-cymene $]$ & & 95 & 97 & & & \\
\hline 6 & Unknown & 15.48 & na & na & 507 & & 2.19 \\
\hline 7 & 1,5,5-trimethyl-6-methylene-cyclohexene & 16.58 & 93 & 93 & 666 & 2.65 & .69 \\
\hline \multirow[t]{2}{*}{8} & $(1 \mathrm{R}, 2 \mathrm{~S}, 6 \mathrm{~S}, 7 \mathrm{~S}, 8 \mathrm{~S})-8$-isopropyl-1,3- & & & & & & \\
\hline & dimethyltricyclo[4-4.0.0(2,7)]dec-3-ene $[=$ copaene $]$ & 16.82 & 99 & $\ldots$ & 700 & .63 & $\ldots$ \\
\hline 9 & 1,7,7-trimethyl-bicyclo[2.2.1]heptan-2-one & 17.35 & 91 & 74 & 772 & 2.93 & 1.59 \\
\hline 10 & 3,7-dimethyl-1,6-octadien-3-ol [= R,S-linalool $]$ & 18.51 & 64 & 80 & 922 & 1.18 & 1.22 \\
\hline \multirow[t]{2}{*}{11} & 1,7,7-trimethyl-bicyclo[2.2.1]hept-2-yl ester [= acetic acid] & 19.15 & 98 & 97 & 1001 & .99 & .59 \\
\hline & Bicyclo[2.2.1]heptan-2-ol, 1,7,7-trimethyl-, acetate & & 98 & 98 & & & \\
\hline \multirow[t]{2}{*}{12} & 1a,2,3,5,6,7,7a,7b-octahydro-1,1,7,7a-tetramethyl- & & & & & & \\
\hline & 1H-cyclopropa[a]naphthalene & 19.35 & 93 & $\cdots$ & 1026 & .77 & $\cdots$ \\
\hline 13 & $\begin{array}{l}\text { (1R,2S,6S,7S,8S)-8-isopropyl-1,3-dimethyltricyclo[4.4.0.0(2,7)]dec- } \\
\text { 3-ene [= caryophyllene }]\end{array}$ & 19.46 & 99 & $\ldots$ & 1039 & 1.13 & .. \\
\hline 14 & 4-methyl-1-(1-methylethyl)-3-cyclohexen-1-ol [= terpinen-4-ol] & 19.78 & 96 & 96 & 1077 & 2.60 & 1.17 \\
\hline 15 & Decanoic acid, ethyl ester & 20.67 & $\ldots$ & 95 & 1179 & $\ldots$ & .68 \\
\hline 16 & Unknown & 20.78 & na & na & 1191 & .82 & .79 \\
\hline 17 & $\begin{array}{l}\text { 1a,2,3,3a,4,5,6,7b-octahydro-1,1,3a,7-tetramethyl-1H- } \\
\text { cyclopropa[a]naphthalene }\end{array}$ & 21.06 & 94 & .. & 1222 & .91 & $\ldots$ \\
\hline 18 & Ethyl trans-4-decenoate & 21.34 & 93 & 98 & 1253 & 1.47 & 9.22 \\
\hline 19 & Unknown & 21.95 & na & na & 1319 & $\ldots$ & .27 \\
\hline \multirow[t]{2}{*}{20} & 1a,2,3,4,4a,5,6,7b-octahydro-1,1,4,7-tetramethyl- & & & & & & \\
\hline & 1-H-cycloprop[e]azulene & 21.99 & 99 & $\cdots$ & 1323 & 1.13 & .. \\
\hline 21 & Unknown & 22.06 & na & na & 1330 & $\cdots$ & .56 \\
\hline 22 & $\begin{array}{l}\text { 1-methyl-5-methylene-8-(1-methylethyl)-1,6-cyclodecadiene } \\
\text { [= germacrene D] }\end{array}$ & 22.14 & 96 & .. & 1339 & 6.24 & $\cdots$ \\
\hline 23 & Unknown & 22.15 & na & na & 1340 & $\ldots$ & 2.30 \\
\hline 24 & $\begin{array}{l}\text { 1,2,3,5,6,8a-hexahydro-4,7-dimethyl-1-(1-methylethyl)- } \\
\text { naphthalene }\end{array}$ & 23.29 & 97 & 96 & 1457 & .80 & .23 \\
\hline 25 & Unknown & 23.44 & na & na & 1471 & .53 & .42 \\
\hline 26 & 2,4-decadienoic acid, methyl ester & 24.22 & $\ldots$ & 87 & 1548 & $\ldots$ & .17 \\
\hline 27 & Unknown & 24.95 & na & na & 1617 & 1.05 & .89 \\
\hline 28 & Unknown & 25.17 & na & na & 1637 & $\ldots$ & .19 \\
\hline 29 & Ethyl 2,4-trans, cis-decadienoate & 25.27 & 96 & $\ldots$ & 1646 & 23.81 & $\ldots$ \\
\hline 30 & Hexanoic acid [= caproic acid] & 25.44 & 83 & 64 & 1662 & 4.69 & 39.01 \\
\hline 31 & Unknown & 26.32 & na & na & 1741 & .52 & .41 \\
\hline 32 & $\begin{array}{l}\text { 2,6-bis(1,1-dimethylethyl)-4-methylphenol [= butylated } \\
\text { hydroxytoluene] }\end{array}$ & 26.67 & 96 & .. & 1772 & .48 & $\ldots$ \\
\hline 33 & Unknown & 26.75 & na & na & 1779 & .71 & .36 \\
\hline 34 & Unknown & 26.97 & na & na & 1798 & .66 & $\ldots$ \\
\hline 35 & Unknown & 28.35 & na & na & 1914 & $\ldots$ & .16 \\
\hline 36 & Octanoic acid $[=$ caprylic acid $]$ & 29.91 & $\ldots$ & 93 & 2038 & $\ldots$ & 1.36 \\
\hline \multirow[t]{2}{*}{37} & Decahydro-1,1,7-trimethyl-4-methylene- & & & & & & \\
\hline & 1H-cycloprop[e]azulen-7-ol & 30.87 & 97 & 81 & 2112 & .88 & .39 \\
\hline 38 & Unknown & 31.81 & na & na & 2182 & $\ldots$ & .31 \\
\hline 39 & Unknown & 38.42 & na & na & 2621 & $\cdots$ & .30 \\
\hline 40 & $n$-hexadecanoic acid [= palmitic acid] & 44.92 & .. & 97 & 2984 & $\ldots$ & .71 \\
\hline
\end{tabular}

Note. Compounds arranged according to retention time, excluding those identified from blank controls. Compounds with identity likelihood estimated as $<80 \%$ listed as "Unknown." IUPAC $=$ International Union of Pure and Applied Chemistry; na $=$ not applicable; RT $=$ retention time.

a Common names in brackets, if applicable. 


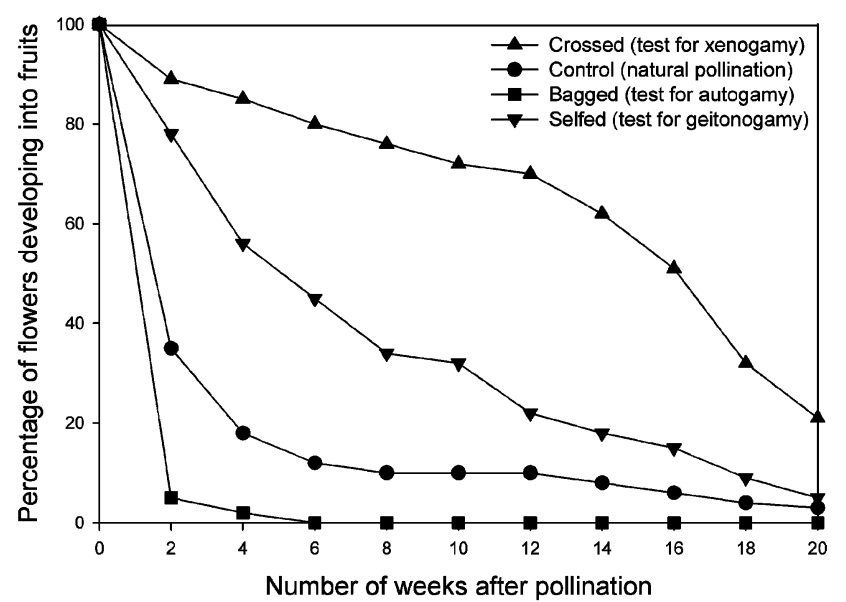

Fig. 9 Percentage of fruit survival after pollination treatments in Xylopia championii.

The unidentified ant species (Formicidae) is unlikely to be an effective pollinator, since individuals were observed to be generally diurnal in activity (and hence not active during the receptive phases of the flower) and were not observed to move actively between flowers. Ants are social insects and are unlikely to be efficient pollinators (Jolivet 1996).

\section{Floral Temperature}

The temperature within the floral chamber of X. championii is elevated to ca. $8^{\circ} \mathrm{C}$ above ambient levels (fig. 8). The coincidence of elevated temperatures with the onset of both stigmatic receptivity and anther dehiscence and the drop in temperature correlated with the interim phase suggests that the heat is generated by the flower rather than merely daytime heat that is retained into the night by the floral chamber. This is rather equivocal evidence of thermogenesis, however, because no evidence is presented for the existence of specific heat-producing tissues in the flower. The floral visitors nevertheless experience elevated temperatures within the floral chamber, irrespective of the origin of this heat. Elevated floral temperatures have previously been reported in several other Xylopia species (Küchmeister et al. 1998; Jürgens et al. 2000; Webber 2002; Silberbauer-Gottsberger et al. 2003), although it was noted as being absent in the thrips-pollinated species X. aromatica (Gottsberger 1970; Jürgens et al. 2000).
Elevated floral temperatures have also been reported for several other genera in the family, including Anaxagorea (Küchmeister et al. 1998; Jürgens et al. 2000), Annona (Gottsberger 1970, 1989a, 1989b, 1999; Gottsberger and SilberbauerGottsberger 1988; Maas-van de Kamer 1993; SilberbauerGottsberger et al. 1997), Cymbopetalum (Murray 1993; Webber and Gottsberger 1993), Duguetia (Küchmeister et al. 1998; Silberbauer-Gottsberger et al. 2001, 2003), Enicosanthum (Silberbauer-Gottsberger et al. 2003), and Polyalthia (Ratnayake et al. 2006a), all of which are beetle pollinated. It is likely that elevated floral temperature is more widespread in the Annonaceae than these data suggest, however, since it has not been investigated in most previous studies.

A possible role for elevated floral temperature is as a heat reward for floral visitors (Seymour and Schultze-Motel 1996; Seymour et al. 1998, 2003). By providing beetles with an energy reward, the flower allows them to conserve considerable levels of energy required for feeding, mating, and initiating flight. The temperatures maintained by thermogenic flowers are typically in the range favored by active beetles (Seymour and Schultze-Motel 1997); the flowers therefore assist with the maintenance of the body temperature of the beetles and stimulate their reproductive behavior, feeding, and digestion (Bernal and Ervik 1996; Patiño et al. 2000; Thien et al. 2000). Significantly, beetles require high thoracic temperatures (often above $30^{\circ} \mathrm{C}$ ) to initiate flight (Seymour and Schultze-Motel 1996, 1997; Seymour et al. 2003).

Recent research has found that some beetles (including some Curculionidae; Hausmann et al. 2004) have infrared sensors known as IR sensilla or IR pit organs, which detect infrared radiation (Schmitz et al. 1997; Hammer et al. 2001; Sowards et al. 2001). Although there is no evidence that such sensors exist on the pollinators of X. championii, it is possible that the heat is generated in the flower as a direct attractant rather than simply an energy reward. Alternatively, it can also be speculated that floral heat may simply encourage the beetles to enter the floral chamber after they have been attracted to the flower by olfactory cues (cf. blowfly pollination of Helicodiceros muscivorus; Angioy et al. 2004).

\section{Floral Scent}

Many of the floral volatiles identified from X. championii are commonly produced by flowers of other angiosperms (Knudsen et al. 2006). Very few previous studies have focused on floral scent chemistry in the Annonaceae, although studies of Cananga (Ma et al. 1988); Anaxagorea, Duguetia,

Table 3

Percentage Fruit Set following Controlled-Pollination Experiments on Xylopia championii

\begin{tabular}{lccrr}
\hline & \multicolumn{4}{c}{ Pollination treatment } \\
\cline { 2 - 5 } & Control & Crossed & Selfed & Bagged \\
\hline Number of flowers treated & 238 & 152 & 260 & 132 \\
Number of individuals treated & 8 & 8 & 8 & 8 \\
Percentage fruit set (mean \pm SD) & $5.0 \pm 3.4^{\mathrm{A}}$ & $29.4 \pm 12.3^{\mathrm{B}}$ & $3.1 \pm 1.7^{\mathrm{A}}$ & 0 \\
\hline
\end{tabular}

Note. Percentage fruit set was compared among treatments using ANOVA after log transformation and discriminated using the Tukey HSD test. Treatments with the same superscript letter do not differ significantly $(P<0.05)$. Results of flowers bagged before pistillate phase were excluded from the analysis due to 0 values. 
Rollinia, and Xylopia (Jürgens et al. 2000); and Asimina (Goodrich et al. 2006) all reveal a broadly similar range of compounds to those found in X. championii.

The fruity odor of $X$. championii flowers suggests that pollinators may be attracted to the flowers by scents that mimic fruits. This hypothesis is reinforced by the common possession of several volatile compounds (or closely allied compounds) in both the floral scent of X. championii and in the fruits of other Annonaceae species. Germacrene D (compound 22; see table 2), for example, occurs in the fruits of Anaxagorea dolichocarpa (Fournier et al. 1994), Annona atemoya (Bartley 1987), and Xylopia aromatica (Stashenko et al. 2004); the related compound bicyclogermacrene occurs in the fruits of A. atemoya (Wyllie et al. 1987); and hexanoic acid (compound 30) occurs in the fruits of Annona cherimola (Idstein et al. 1984).

There is also equivocal evidence to suggest that some of the volatile components of the floral scent of $X$. championii may act as beetle attractants by mimicking insect pheromones. Although relatively little is known of the chemical attractants of curculionid beetles such as Endaeus, there is an extensive literature relating to the pheromones of other insect groups. The following floral volatiles isolated from X. championii have been identified as insect pheromones (El-Sayed 2006 and references therein): 3 -carene (compound 1; see table 2); 1-methyl-4-(1-methylethyl)-benzene (= $p$-cymene, one of the possible identities of compound 5); 3,7-dimethyl-1,6octadien-3-ol (= R,S-linalool; compound 10); acetic acid (one of the possible identities of compound 11); caryophyllene (compound 13); 4-methyl-1-(1-methylethyl)-3-cyclohexen-1-ol (= terpinen-4-ol; compound 14); 1-methyl-5-methylene-8(1-methylethyl)-1,6-cyclodecadiene (= germacrene D; compound 22); ethyl 2,4-trans, cis-decadienoate (compound 29); hexanoic acid (= caproic acid; compound 30$)$; octanoic acid (= caprylic acid; compound 36$)$; and $n$-hexadecanoic acid (= palmitic acid; compound 40). Although these compounds elicit a variety of responses in insects, in most cases they act as aggregation pheromones; compounds that have specifically been highlighted as beetle attractants include $1,10,13,30$, and 40 (table 2). These conclusions are speculative, however, in the absence of empirical studies. The lack of strong visual cues nevertheless strongly suggests that the beetles are primarily attracted to the flowers in response to some form of olfactory cues.

Naphthalene was one of the volatiles observed in the floral scent of X. championii, although it was excluded from table 2 because it was detected in similar quantities in the blank controls. It has previously been isolated in significant quantities from the floral scents of Rollinia, Xylopia (Jürgens et al. 2000), and Magnolia (Azuma et al. 1996), although there is some disagreement whether it is likely to be of anthropogenic origin (as suggested by Jürgens et al. 2000) or whether it functions to protect flowers against herbivory (as suggested by Azuma et al. 1996). The data for X. championii suggests that in this case, at least, it appears to be an artifact.

\section{Plant Breeding System}

The P/O ratio value calculated for X. championii $(2625 \pm$ $219)$ suggests that it is likely to possess an obligately xenogamous breeding system, according to Cruden's (1977) scheme. Caution is required in the interpretation of these results, however, since $\mathrm{P} / \mathrm{O}$ values are known to vary within and between populations and to be affected by various factors, including timing of flower formation in the flowering season (Cruden 2000 and references therein). Furthermore, Kress (1981) and Cruden (2000) found that the $\mathrm{P} / \mathrm{O}$ ratio is lower in species in which pollen is dispersed in tetrads, as in $X$. championii. The $\mathrm{P} / \mathrm{O}$ ratio is only imperfectly correlated with breeding system, however, and the field-based controlledpollination experiments can be expected to provide a more accurate determination of breeding system.

None of the flowers that were bagged to exclude pollinators before the onset of the pistillate phase developed into fruits (fig. 9), indicating that autogamy is unlikely. This is presumably due to the marked protogyny observed, with the 6-8-h unreceptive interim phase separating the pistillate and staminate phases, but may also be due to a possible self-incompatibility mechanism.

All the other pollination treatments resulted in limited fruit set (fig. 9), although with a gradual decline in the number of fruits as a result of self-pollination, animal consumption (primarily by birds), weather conditions, inbreeding depression (for geitonogamous crosses; see discussion below), or overproduction (immature fruit abscission when the carrying capacity of an individual tree is exceeded). The relatively low flowering and fruiting intensities of individuals suggest that the latter explanation is less likely, however.

Levels of fruit set following artificial cross-pollination exceeded those following artificial geitonogamous self-pollination, suggesting that the population possesses a xenogamous breeding system. This breeding system is characteristic of woody species throughout the tropics (Bawa et al. 1985b). The lower fruit set following self-pollination is possibly due to a partial self-incompatibility mechanism: the selfing rate $(3.1 \%)$ suggests that X. championii is intermediate between being selfincompatible and self-compatible (fide Dafni 1992); and the ISI was calculated as 0.10 , indicating that individuals are likely to be mostly self-incompatible (fide Zapata and Arroyo 1978). Significantly, however, the gradual abscission of immature fruits after self-pollination (fig. 9) may be due to inbreeding within the population (Charlesworth and Charlesworth 1987; Stacy 2001); this is common in fragmented habitats (Harris and Johnson 2004). There are very few reports of selfincompatibility in the Annonaceae, possibly because of widespread protogyny in the family, which would limit the potential benefits of such a system. Partial self-incompatibility has previously been reported, however, in Asimina (Norman et al. 1992), Polyalthia (Rogstad 1994; Ratnayake et al. 2006b), Sapranthus (Bawa 1974), and Uvaria (Nagamitsu and Inoue 1997).

The levels of fruit set following artificial cross-pollination significantly exceeded those resulting from natural (open) pollination (table 3; fig. 9). This may be due to the scarcity of pollinators, at least during the assessment period, and it would imply that annual fluctuations in the population size of the pollinator may significantly affect the reproductive success of X. championii.

\section{Conclusions}

The effective pollinator of $X$. championii is shown to be a species of Endaeus weevil (Curculionidae). The beetles are 
attracted to the flowers by a strong fruity scent and also possibly heat generated within the flower. The rewards provided by the flowers include heat energy (for the maintenance of body temperature), and the enclosed floral chamber may furthermore provide protection from predators and a site for meeting mates. It is also possible that the beetles are rewarded with pollen grains as food, although the evidence for this is circumstantial in the absence of gut contents analysis. Evidence of beetle damage to the petals was slight and is only weak evidence of feeding on petal tissue.

Although $X$. championii flowers show clear adaptations for small-beetle pollinations, the Endaeus beetles are generalist fruit eaters and are not specialized as pollinators. There is no evidence to suggest any specific one-to-one adaptation between the plant and beetle species, and it is likely that other fruit beetles may perform a role in pollination in different flowering periods or at different sites. There is a considerable body of data to indicate that the specificity of plant-pollinator interactions in the beetle-pollinated Annonaceae is with functional groups of beetles rather than with specific species of beetle (Saunders, forthcoming).

The comparatively low levels of fruit set in natural (open) pollination treatments suggest that pollinator availability may be a limiting factor and that annual fluctuations in the population size of the pollinator are likely to affect the reproductive success of the tree. Constraint of plant-pollinator interactions is prevalent among tropical lowland rainforest trees (Bawa et al. 1985a).

The flowers of $X$. championii are markedly protogynous, with a $6-12$-h nonfunctional interim period between the pis- tillate and staminate phases. This clearly precludes autogamy, although geitonogamy (between different flowers belonging to the same individual) is possible because of the apparent lack of intraindividual synchrony in the sexual maturation of flowers. The co-occurrence of pistillate- and staminate-phase flowers on single individuals therefore suggests that self-pollination is possible despite the existence of complete intrafloral dichogamy. Significantly, the results of artificial controlled-pollination experiments indicate that $X$. championii possesses an essentially xenogamous breeding system. The low levels of fruit set following geitonogamous self-pollination are probably indicative of inbreeding depression.

\section{Acknowledgments}

This research was funded by a grant to R. M. K. Saunders from the University of Hong Kong Committee on Research and Conference Grants. We are grateful to the following: the Sri Lankan Forest Department for permission to conduct this research in the Sinharaja Forest Reserve; the Sri Lankan Wildlife Department for permission to export samples; U. G. U. R. Bandara, M. G. Gunadasa, S. A. W. S. Kumara, N. Narampanawa, T. M. Ratnayake, A. Tennakoon, and J. Tennakoon for assisting with the collection of field data; Dr. A. Wikramasinghe and J. Lai for assistance with the GC-MS analyses; the staff of the Natural History Museum, London, for the identification of floral visitors; Ngai Yuen Yi for drawing figures 4 and 6; and Professor R. T. Corlett, Professor G. Gottsberger, Dr. L. Ramsden, Dr. Y. C. F. Su, and an anonymous reviewer for helpful discussions.

\section{Literature Cited}

Andrade BM, AT Oliveira-Filho, AR Soares 1996 Pollination and breeding system of Xylopia brasiliensis Sprengel (Annonaceae) in south-eastern Brazil. J Trop Ecol 12:313-320.

Angioy A-M, MC Stensmyr, I Urru, M Puliafito, I Collu, BS Hansson 2004 Function of the heater: the dead horse arum revisited. Proc R Soc B (suppl)271:S13-S15.

Ashton PMS, CVS Gunatilleke, IAUN Gunatilleke 1995 Seedling survival and growth of four Shorea species in a Sri Lankan rainforest. J Trop Ecol 11:263-279.

Azuma H, M Toyota, Y Asakawa 2001 Intraspecific variation of floral scent chemistry in Magnolia kobus DC. (Magnoliaceae). J Plant Res 114:411-422.

Azuma H, M Toyota, Y Asakawa, S Kawano 1996 Naphthalene: a constituent of Magnolia flowers. Phytochemistry 42:999-1004.

Bartley JP 1987 Volatile constituents of custard apple. Chromatographia 23:129-131.

Bawa KS 1974 Breeding systems of tree species of a lowland tropical community. Evolution 28:85-92.

Bawa KS, SH Bullock, DR Perry, RE Coville, MH Grayum 1985a Reproductive biology of tropical lowland rain forest trees. II. Pollination systems. Am J Bot 72:346-356.

Bawa KS, DR Perry, JH Beach $1985 b$ Reproductive biology of tropical lowland forest trees. I. Sexual systems and incompatibility mechanisms. Am J Bot 72:331-345.

Bernal R, F Ervik 1996 Floral biology and pollination of the dioecious palm Phytelephas seemannii in Colombia: an adaptation to staphylinid beetles. Biotropica 28:682-696.

Carvalho R, AC Webber 2000 Biologia floral de Unonopsis guatte- rioides (A. D.C.) R.E. Fr., uma Annonaceae polinizada por Euglossini. Rev Bras Bot 23:421-425.

Charlesworth D, B Charlesworth 1987 Inbreeding depression and its evolutionary consequences. Annu Rev Ecol Syst 18:237-268.

Cruden RW 1977 Pollen-ovule ratios: a conservative indicator of breeding systems in flowering plants. Evolution 31:32-46.

2000 Pollen grains: why so many? Plant Syst Evol 222:143165.

Dafni A 1992 Pollination ecology: a practical approach. Oxford University Press, Oxford.

Davis SD, VH Heywood, AC Hamilton 1995 Centres of plant diversity: a guide and strategy for their conservation. WWF and IUCN, Cambridge.

El-Sayed AM 2006 The Pherobase: database of insect pheromones and semiochemicals. http://www.pherobase.com.

Fournier G, A Hadjiakhoondi, B Charles, M Leboeuf, A Cavé 1994 Volatile components of Anaxagorea dolichocarpa fruit. Biochem Syst Ecol 22:605-608.

Galen C, RC Plowright 1987 Testing the accuracy of using peroxidase activity to indicate stigma receptivity. Can J Bot 65:107-111.

Goodrich KR, ML Zjhra, CA Ley, RA Raguso 2006 When flowers smell fermented: the chemistry and ontogeny of yeasty floral scent in pawpaw (Asimina triloba: Annonaceae). Int J Plant Sci 167: 33-46.

Gottsberger G 1970 Beiträge zur Biologie von Annonaceen-Blüten. Oesterr Bot Z 118:237-279.

1974 The structure and function of the primitive angiosperm flower: a discussion. Acta Bot Neerl 23:461-471. 
1985 Pollination and dispersal in the Annonaceae. Annonaceae Newsl 1:6-7.

$1989 a$ Beetle pollination and flowering rhythm of Annona spp. (Annonaceae) in Brazil. Plant Syst Evol 167:165-187.

$1989 b$ Comments on flower evolution and beetle pollination in the genera Annona and Rollinia (Annonaceae). Plant Syst Evol 167:189-194.

1999 Pollination and evolution in Neotropical Annonaceae. Plant Species Biol 14:143-152.

Gottsberger G, I Silberbauer-Gottsberger 1988 Pollination strategies of Annona species from the Cerrado vegetation in Brazil. Lagascalia 15:665-672.

Gunatilleke CVS, IAUN Gunatilleke 1981 The floristic composition of Sinharaja: a rain forest in Sri Lanka, with special reference to endemics and dipterocarps. Malays For 44:386-396.

Hammer DX, H Schmitz, A Schmitz, HG Rylander, AJ Welch 2001 Sensitivity threshold and response characteristics of infrared detection in the beetle Melanophila acuminata (Coleoptera: Buprestidae). Comp Biochem Physiol A 128:805-819.

Harris LF, SD Johnson 2004 The consequences of habitat fragmentation for plant-pollinator mutualisms. Int J Trop Insect Sci 24: 29-43.

Hausmann C, J Samietz, S Dorn 2004 Visual orientation of overwintered Anthonomus pomorum (Coleoptera: Curculionidae). Environ Entomol 33:1410-1415.

Huber H 1985 Annonaceae. Pages 1-75 in MD Dassanayake, FR Fosberg, eds. A revised handbook to the flora of Ceylon. Vol 5. Amerind, New Delhi.

Idstein H, W Herres, P Schreier 1984 High-resolution gas chromatography-mass spectrometry and-Fourier transform infrared analysis of cherimoya (Annona cherimolia, Mill.) volatiles. J Agric Food Chem 32:383-389.

Jolivet P 1996 Ants and plants: an example of coevolution. 2nd ed. Backhuys, Leiden.

Jürgens A, AC Webber, G Gottsberger 2000 Floral scent compounds of Amazonian Annonaceae species pollinated by small beetles and thrips. Phytochemistry 55:551-558.

Keßler PJA 1993 Annonaceae. Pages 93-129 in K Kubitzki, JG Rohwer, V Bittrich, eds. The families and genera of vascular plants. Vol 2. Springer, Berlin.

Knudsen JT, R Eriksson, J Gershenzon, B Ståhl 2006 Diversity and distribution of floral scent. Bot Rev 72:1-120.

Kovats E 1965 A retention index system. Adv Chromatogr 1:229235.

Kress WJ 1981 Sibling competition and evolution of pollen unit, ovule number, and pollen vector in angiosperms. Syst Bot 6:101112.

Kress WJ, JH Beach 1994 Flowering plant reproductive systems. Pages 161-182 in LA McDade, KS Bawa, HA Hespenheide, GS Hartshorn, eds. La Selva: ecology and natural history of a Neotropical rain forest. University of Chicago Press, Chicago.

Küchmeister H, AC Webber, I Silberbauer-Gottsberger, G Gottsberger 1998 A polinização e sua relação com a termogênese em espécies de Arecaceae e Annonaceae da Amazônia central. Acta Amazonica 28: 217-245.

Lamoureux $\mathrm{CH} 1975$ Phenology and floral biology of Monodora myristica (Annonaceae) in Bogor, Indonesia. Ann Bogor 6:1-25.

Ma L, Y Zeng, Y Sun, Z Wu, M Liu 1988 Studies on the aroma volatile constituents of ylang-ylang flowers by gas chromatography and gas chromatography-mass spectrometry. Sepu 6:11-18.

Maas-van de Kamer H 1993 Floral biology of Anaxagorea dolichocarpa, and some notes on flower biology in other Annonaceae. Annonaceae Newsl 9:19-24.

Minitab 2001 Minitab, release 13.20. Minitab, State College, PA.

Momose K, T Nagamitsu, T Inoue 1998a Thrips cross-pollination of
Popowia pisocarpa (Annonaceae) in a lowland dipterocarp forest in Sarawak. Biotropica 30:444-448.

Momose K, T Yumoto, T Nagamitsu, M Kato, H Nagamasu, S Sakai, RD Harrison, T Itioka, AA Hamid, T Inoue 1998b Pollination biology in a lowland dipterocarp forest in Sarawak, Malaysia. I. Characteristics of the plant-pollinator community in a lowland dipterocarp forest. Am J Bot 85:1477-1501.

Murray NA 1993 Revision of Cymbopetalum and Porcelia (Annonaceae). Syst Bot Monogr 40:1-121.

Nagamitsu T, T Inoue 1997 Cockroach pollination and breeding system of Uvaria elmeri (Annonaceae) in a lowland mixed-dipterocarp forest in Sarawak. Am J Bot 84:208-213.

Norman EM 2003 Reproductive biology of Deeringothamnus rugelii and D. pulchellus (Annonaceae). Taxon 52:547-555.

Norman EM, D Clayton 1986 Reproductive biology of two Florida pawpaws: Asimina obovata and A. pygmaea (Annonaceae). Bull Torrey Bot Club 113:16-22.

Norman EM, K Rice, S Cochran 1992 Reproductive biology of Asimina parviflora (Annonaceae). Bull Torrey Bot Club 119:1-5.

Olesen JM 1992 Flower mining by moth larvae vs. pollination by beetles and bees in the cauliflorous Sapranthus palanga (Annonaceae) in Costa Rica. Flora 187:9-15.

Patiño S, J Grace, H Bänzinger 2000 Endothermy by flowers of Rhizanthes lowii (Rafflesiaceae). Oecologia 124:149-155.

Ratnayake RMCS, IAUN Gunatilleke, DSA Wijesundara, RMK Saunders 2006a Reproductive biology of two sympatric species of Polyalthia (Annonaceae) in Sri Lanka. I. Pollination by curculionid beetles. Int J Plant Sci 167:483-493.

Ratnayake RMCS, YCF Su, IAUN Gunatilleke, DSA Wijesundara, RMK Saunders $2006 b$ Reproductive biology of two sympatric species of Polyalthia (Annonaceae) in Sri Lanka. II. Breeding systems and population genetic structure. Int J Plant Sci 167:494501.

Rogstad SH 1993 Variability in timing of sexual phases in the North American pawpaw, Asimina triloba (L.) Dunal (Annonaceae). Trillium 1993:5-8.

1994 The biosystematics and evolution of the Polyalthia hypoleuca species complex (Annonaceae) of Malesia. III. Floral ontogeny and breeding systems. Am J Bot 81:145-154.

Saunders RMK Forthcoming The diversity and evolution of pollination systems in the basal grade and "long branch clade" of the Annonaceae. In LW Chatrou, H Rainer, JE Richardson, RHJ Erkens, eds. The natural history of the Annonaceae. ARG Gantner, Ruggell, Liechtenstein.

Schmitz H, H Bleckmann, M Murtz 1997 Infrared detection in a beetle. Nature 386:773-774.

Seymour RS, P Schultze-Motel 1996 Thermoregulating lotus flowers. Nature 383:305.

- 1997 Heat-producing flowers. Endeavour 21:125-129.

Seymour RS, P Schultze-Motel, I Lamprecht 1998 Heat production by sacred lotus flowers depends on ambient temperature, not light cycle. J Exp Bot 49:1213-1217.

Seymour RS, CR White, M Gibernau 2003 Heat reward for insect pollinators. Nature 426:243-244.

Silberbauer-Gottsberger I, G Gottsberger, AC Webber 2003 Morphological and functional flower characteristics of New and Old World Annonaceae with respect to their mode of pollination. Taxon 52:701-718.

Silberbauer-Gottsberger I, RA Gottsberger, G Gottsberger 1997 Rhythm of flowering and pollination of a hybrid population of Annona in a small cerrado area in Mato Grosso, Brazil. Annonaceae Newsl 11:55-60.

Silberbauer-Gottsberger I, AC Webber, H Küchmeister, G Gottsberger 2001 Convergence in beetle-pollinated central Amazonia Annonaceae, Araceae, Arecaceae, and Cyclanthaceae. Pages 165-183 in 
G Gottsberger, S Liede, eds. Life forms and dynamics in tropical forests. Cramer, Berlin.

Sowards LA, H Schmitz, DW Tomlin, RR Naik, MO Stone 2001 Characterization of beetle Melanophila acuminata (Coleoptera: Buprestidae) infrared pit organs by high-performance liquid chromatography/mass spectrometry, scanning electron microscope, and Fourier transform-infrared spectroscopy. Ann Entomol Soc Am 94: 686-694.

Stacy EA 2001 Cross-fertility in two tropical tree species: evidence of inbreeding depression within populations and genetic divergence among populations Am J Bot 88:1041-1051.

Stashenko EE, BE Jaramillo, JR Martínez 2004 Analysis of volatile secondary metabolites from Colombian Xylopia aromatica (Lamarck) by different extraction and headspace methods and gas chromatography. J Chromatogr A 1025:105-113.

Su YCF, JB Mols, W Takeuchi, PJA Keßler, RMK Saunders 2005 Reassessing the generic status of Petalolophus (Annonaceae): evidence for the evolution of a distinct sapromyophilous lineage within Pseuduvaria. Syst Bot 30:494-502.

Su YCF, RMK Saunders 2006 Monograph of Pseuduvaria (Annonaceae). Syst Bot Monogr 79:1-204, pls 1-3.

Thien LB, H Azuma, S Kawano 2000 New perspectives on the pol- lination biology of basal angiosperms. Int J Plant Sci 161(suppl): S225-S235.

Waser NM, L Chittka, MV Price, NM Williams, J Ollerton 1996 Generalization in pollination systems, and why it matters. Ecology 77:1043-1060.

Webber AC 2002 Floral biology and pollination of some Neotropical Annonaceae. Annonaceae Newsl 13:18-21.

Webber AC, G Gottsberger 1993 Floral biology and pollination of Cymbopetalum euneurum in Manaus, Amazonia. Annonaceae Newsl 9:25-28.

1995 Floral biology and pollination of Bocageopsis multiflora and Oxandra euneura in central Amazonia, with remarks on the evolution of stamens in Annonaceae. Feddes Repert 106:515-524.

Willson MF, DW Schemske 1980 Pollinator limitation, fruit production, and floral display in pawpaw (Asimina triloba). Bull Torrey Bot Club 107:401-408.

Wyllie SG, D Cook, JJ Brophy, KM Richter 1987 Volatile flavor components of Annona atemoya (custard apple). J Agric Food Chem 35:768-770.

Zapata TR, MTK Arroyo 1978 Plant reproductive ecology of a secondary deciduous tropical forest in Venezuela. Biotropica 10:221230. 